\title{
Gordon, Agáta. 2011. Magdolna lányai: Az Úrnö könyve (The Womenfolk of the Magdolna Quarter: The Lady's Book). Budapest: Centrifuga eKiadó. 89 pp.
}

\section{Reviewed by Angéla Kóczé, Visiting Assistant Professor, Wake Forest University}

Agáta Gordon (b. 1963) is a Hungarian feminist writer and poet who has already enriched contemporary Hungarian experimental literary writing, for example with her Kecskerúzs (Goat Rouge; Budapest: Magvetö, 1997). The novelty of her 2011 e-book Magdolna lányai: Az Úrnö könyve, though, goes beyond Hungarian literary creation. It is a Central and Eastern European feminist account of the racialized and spatially segregated Roma quarter of Magdolna in Budapest focusing on its women, a subgroup whose voices were hitherto unheard. Gordon's book is innovative in that it presents a new feminist genre, which bridges literature and ethnography, with the result that now these voices and views are the subject not only of traditional and literary expression but of Roma ethnography in Hungary.

Gordon's views about these marginalized women correspond with Western feminist theories that advocate a shift towards those whose experiences and views have been so far ignored or discredited as cultural knowledge and treated, if at all, as merely personal troublesome experiences (on these issues see: Patricia Hill Collins, Black Feminist Thought: Knowledge, Consciousness, and the Politics of Empowerment [New York: Routledge, 2000]; Donna Haraway, "Situated Knowledges: The Science Question in Feminism and the Privilege of Partial Perspectives," Feminist Studies 14.3 (1988), 575-599; Sandra G. Harding, "Feminist Standpoint Theory," Whose Science? Whose Knowledge? Thinking from Women's Lives [Ithaca: New York: Cornell UP, 1991], 119-163).

Even the language of Magdolna lányai is experimental, something between descriptive prose and rhythmical poetry, with the book's short chapters usually divided into short paragraphs. Gordon's literary depiction centers on Romani women's everyday life and sense of being writhed in a limited and limiting social arena. It is truly a voyage into a cruel, vulnerable and mysterious land called Magdolna Quarter, which is full of smells, sounds, sights, living anecdotes and extraordinary female characters. Gordon writes with great passion and wit about her Roma neighbors as well as about non-Roma experts and researchers who are the agents of change in the Magdolna quarter. Regardless of their identity and ethnicity, these are the main characters in Gordon's narrative, and their major action is their having founded the "Committee for the Evolution of Mothers." As the name of the committee indicates, the notions of motherearth, mother-child relations, and women's empowerment are at the center of this book.

Gordon herself appears in the book through the character called Etella József (probably alluding to Etelka József, poet Attila József 's sister), a poet and a volunteer in the neighborhood who just moved into a "narcotic and Roma ghetto" (3), and who would like to pursue her fieldwork as a researcher of this ghetto. Gordon's narrative is richly detailed, moving, ironic and humorous as she delineates the interaction of the neighborhood's Roma inhabitants, some of whom live periodically with József (or she with them) in the same quarter and street and even in

(cc) $\mathrm{Br}$

ULLS D-Serle 
Kóczé, Angéla. "Gordon, Agáta. 2011. Magdolna lányai: Az Úrnő könyve (The Womenfolk of the Magdolna Quarter: The Lady's Book)." Hungarian Cultural Studies. e-Journal of the American Hungarian Educators Association, Volume 7 (2014): http://ahea.pitt.edu DOI: 10.5195/ahea.2014.152

the same house. At a semi-formal meeting with a groups of educated and mainly middle or upper-middle class women who come together to discuss the situation of Magdolna Quarter and ways to help its inhabitants, József declares that she will give them all periodical updates about her experiences and reflections as she gathers knowledge in and about this ghetto. This act in fact legitimizes her role as a chronicler of the ghetto.

A reflexive feminist, Gordon constantly challenges and questions her own authority of writing about the life of the ghetto. She clearly shares the life of these "unemployed and homeless" people (6), but her non-Romani identity gradually positions her and her alter-ego Etella József in the place of a chronicler who came to terms with the dissonance of being part of the classical white, middle-class Hungarian ethnographers, who usually come to live with Roma people for only a limited period, and thus remain outsiders to these communities. I believe that Gordon's positioning of herself in the role of the "researcher" is in itself a critique of existing ethnographical work on Roma people that is often carried out without enough reflection on issues of the politics of location.

It is only in Chapter Eight that we discover that József even has a quasi-research question about the place of power and love in her research locale. This question is significantly different from the usual academic inquiry, in that this researcher is interested neither in the Roma people and their ghetto culture nor in their marginalization by general society, but in these people's -especially women's -- emotions, sensations and behaviors that all make up their women's power in the ghetto. Orbánné Vica [Mrs. Vica Orbán] and her remarkable daughters, Johanna Teknős, Terra, Angelika, Cilin Nindzsa, as well as many other less developed characters, are all presented as truly possessing some incredible female "magic." At the same time, it turns out from their subtle stories that they can be hurtful towards each other and that their mysterious or "magical" female power is often used against one another in rather destructive ways.

Although this book is entirely concerned with women's lives, it does have a short section about men and masculinity within the ghetto hierarchy. Judging by Gordon's book, though, men are not at the center, and women, or rather mothers, are the ones in charge of the community as the family breadwinners. Interestingly, most of these mothers are very young women: "They are children too" (63), as the writer realizes, and a large number of them are already grandmothers before they turn thirty-five or forty. Somewhat below the mothers in the ghetto hierarchy are young girls, who hold some power through their "assets" of the body and its reproductive potential. Next in hierarchy are the men, who are internally divided by age groups. Compared to women, the men are even more oppressed, powerless, lethargic and depressed by their life circumstances. In fact, it would have been interesting to read more about the complex relationships of women and men in the ghetto than is afforded in Gordon's book. The last group in the ghetto's social hierarchy is that of children, who are described as energetic, innocent and having no one to control their unlimited freedom. Freedom, therefore, is conceptualized differently in Magdolna than in an average middle class European neighborhood, and in the ghetto it is believed that "freedom for children is equal to family negligence" (65). At any rate, as József makes clear, mothers and children are at the center of life in the ghetto.

The vivid but at times perhaps too detailed portraits of colorful women in the book are rather complicated to follow and toward the end of the book it seems that Gordon herself became exhausted with her narrative and ends it rather abruptly. Notwithstanding these slight flaws, Magdolna lányai is undoubtedly a compelling depiction of the life of women in the Budapest Magdolna Quarter from a combined insider-outsider, at one time literary and ethnographic, unique point of view. 